\title{
An Analysis of Effectiveness of Bancassurance among Customers as an Alternative Distribution Channel in Bangalore
}

\author{
Bhavana Gowda SP \\ Final Year Student \\ Ramaiah University of Applied Sciences \\ Bangalore-560054, India \\ E-mail: mailmebhavanasp@gmail.com \\ Rashmi.R \\ Professor \\ Faculty of Management and Commerce \\ Ramaiah University of Applied Sciences \\ Bangalore-560 054, India \\ E-mail: rashmi.co.mc@msruas.ac.in
}

\begin{abstract}
In this study we had conducted a survey among Customers of Bank in order to know whether they are aware of the concept of Bancassurance and exploring the reasons why customer would like to buy insurance products from banks. Customer attitude to two different distribution channels was calculated by getting the mean of 24 statements on Likert scale. $74 \%$ of the sample was aware of the fact that their banks sell insurance products. It was reported that the reference (56\%) and bank employees (54\%) are the two main information sources for these customers. The respondents emphasized Trust, convenience in terms of location as the main reasons for buying the insurance products from banks instead of Insurance agents and after analyzing 24 statements administered among target sample population we can conclude: Customers feel that insurance agents have more expertise in insurance products than bank employees and can give better advice. It was also found that banks employees give them all the information needed than insurance agents and customers trust bank more than insurance company for all their financial requirements. Therefore, banks in India should try to exploit the existing opportunities to cross-sell insurance products through their branch network.
\end{abstract}

Keywords: Bancassurance, Awareness, Insurance, Bank Employees, Future acceptance.

\section{Introduction}

This chapter is an introduction for the scope and topic of the study, which outlines the significance of Bancassurance. Banking has become a part and parcel of our day-to-day life. Today, banks offer an easy access to a common man. They carry out variety of functions apart from their main functions of accepting deposits and lending. Banking is a service industry. Banks provide financial services to the people, business and industries. Merchant banking, money transfer, credit cards, ATM's are some of the important financial services provided by the modern banks. Indian banking system, over the years has gone through various phrases after establishment of RBI in 1935 according to RBI Act, 1934, during British rule, to function as Central Bank of the country. Earlier Central Bank's functions were being looked after by the Imperial Bank of India. The development of 'Banking' is evolutionary in nature. There is no single answer to the question of what is banking. Because a bank performs a multitude of functions and services which cannot be comprehended into a single definition. For a common man, a bank is a storehouse of money, for a businessman it is an institution of finance and for a worker it may be a depository for his saving. It may be explained in brief as "Banking is what a bank does". But it is not clear enough to understand the subject in full The Oxford dictionary defines a bank as "an establishment for the custody of money which it pays out on a customer's order'. But this definition is also not enough, because it considers the deposit lending and repayment functions only. The meaning of a bank can be understood only by its functions just as a tree is known by its fruits, as any other subjects, it has its own origin, grow th and development.

\section{Objectives of the Study}

- To understand the concepts and models of Bancassurance.

- To analyse the present scenario of Bancassurance in India. 
- To examine whether Indian customers are aware of the concept of Bancassurance i.e. selling of insurance products by banks.

- To examine the preference of Indian customer for buying insurance products from insurance company or the bank and the reason for such preference.

\section{Literature Review}

In most of the emerging economies where spread of insurance sector is not that much strong or level of awareness about various types of financial products are low. The success of bancassurance business model basically depends on the strength of the financial market and economic performance of the country. (Bergheetal. 1999). The paper focuses on the liberalization of European financial market by creating a single insurance market. (Sterzynski, 2003). The new and innovative model of bancassurance each and every target consumer can get the true benefits of the same. The product knowledge about various insurance products is limited among bank staff. (Agarwal. 2004). The paper highlights that there is no unique model of bancassurance operations and its nature and implementation may vary country or region wise. Looking at the increasing phenomenon of developing a financial supermarket it will surely add values to the both players in the form of differentiated product, offering of a wider product mix not only helps the service providers to satisfy the increasing demand of specialized services but also helps to gain. (Brahmametal. 2004). The study is on the emerging trends of bancassurance in Indian market, factors like huge branch network, fee-based earnings for bank staffs and common acceptability of banks among mass consumers vis - a -vis insurance companies play a dominant role- responsible for this growing trend. The problems of bad loans faced by the Indian banks as well as overstaffing situation also forces the banks to take this route. Kind of trust enjoyed by the bank staffs can also be utilized properly. (Sinha (2005). The concept of bancassurance is not new but with changing time and geographical location wise the same model need to be re - oriented. (Kumar. 2008). It was concluded in the study that going by the present pace, bancassurance would turn out to be a common phenomenon rather than an exception in future in India. It would be a 'winwin situation' for all the parties involved i.e. the customer, the insurance companies and the banks. (Karunagaran. 2006).

\section{Database and Methodology}

Data Collection: The methodology includes the information of the features of the Bancassurance in the form of primary data that had been received from the basic users of Bancassurance i.e., the customers who are the actual users. It also includes the information's from the related books \& the related websites. For this research a total of 348 people who had availed Bancassurance from different Banks in Bangalore city have been collected through questionnaire survey.

Primary data: Questionnaire survey was done to collect the opinions of customers of Bangalore City.

Secondary data: This data is collected through Literature reviews, Websites and books.

\section{Results and Discussion}

\begin{tabular}{cc}
\hline Cronbach's Alpha & N of Items \\
\hline .942 & 20 \\
\hline
\end{tabular}

Cronbach's $\alpha$ was used to measure the questionnaire's consistency. The overall coefficient was found to be 0.942 which exceeds the minimal recommendations i.e., 0.90. Therefore, the viability and validity of the instrument is deemed to be sufficient.

\section{Hypothesis}

- Ho- Low mis selling of products, ease of access, satisfaction under one roof, bank showing sincere interest in solving problems has no significance in effects of Bancassurance among customers in building good future in Bangalore.

- $\mathrm{H}_{\mathrm{I}}$ - Low mis selling of products has significance effect in of Bancassurance among customers in building good future.

- $\mathrm{H}_{2}$ - ease of access has significance effect in of Bancassurance among customers in building good future.

- $\mathrm{H}_{3}$ - satisfaction under one roof has significance effect in of Bancassurance among customers in building good future.

- $H_{4}$ - bank showing sincere interest in solving problems has significance effect in of Bancassurance among customers in building good future. 


\section{Correlations}

\begin{tabular}{|c|c|c|c|}
\hline \multicolumn{4}{|l|}{ Correlations } \\
\hline & & Good future & Easy to access \\
\hline \multirow[t]{3}{*}{ Good future } & Pearson Correlation & I & $.658^{m+m}$ \\
\hline & Sig. (2-tailed) & & .000 \\
\hline & $\mathrm{N}$ & 348 & 348 \\
\hline \multirow[t]{3}{*}{ Easy to access } & Pearson Correlation & $.658^{\text {sot }}$ & $\mathrm{I}$ \\
\hline & Sig. (2-tailed) & .000 & \\
\hline & $\mathrm{N}$ & 348 & 348 \\
\hline
\end{tabular}

\begin{tabular}{|c|c|c|c|}
\hline & & Good future & $\begin{array}{c}\text { Low misspelling of } \\
\text { products }\end{array}$ \\
\hline \multirow[t]{3}{*}{ Good future } & $\begin{array}{l}\text { Pearson } \\
\text { Correlation }\end{array}$ & I & $.715^{\text {thr }}$ \\
\hline & $\begin{array}{l}\text { Sig. }(2- \\
\text { tailed) }\end{array}$ & & .002 \\
\hline & $\mathrm{N}$ & 348 & 348 \\
\hline \multirow[t]{3}{*}{ Low misspelling of products } & $\begin{array}{c}\text { Pearson } \\
\text { Correlation }\end{array}$ & $.715^{\text {tha }}$ & $\mathrm{I}$ \\
\hline & $\begin{array}{l}\text { Sig. }(2- \\
\text { tailed) }\end{array}$ & .002 & \\
\hline & $\mathrm{N}$ & 348 & 348 \\
\hline
\end{tabular}

\begin{tabular}{|c|c|c|c|c|}
\hline \multicolumn{5}{|c|}{ Model Summary } \\
\hline Model & $\mathrm{R}$ & R Square & Adjusted R Square & $\begin{array}{l}\text { Std. Error of the } \\
\text { Estimate }\end{array}$ \\
\hline $\mathrm{I}$ & $.834^{\mathrm{a}}$ & .695 & .692 & .360 \\
\hline \multicolumn{5}{|c|}{$\begin{array}{l}\text { a. Predictors: (Constant), bank shows sincere interest in solving, easy to access, enables satisfaction under } \\
\text { one roof, low mis-selling of products }\end{array}$} \\
\hline
\end{tabular}




\begin{tabular}{|c|c|c|c|c|c|c|}
\hline \multicolumn{7}{|c|}{ ANOVA $^{a}$} \\
\hline & Model & Sum of Squares & $\overline{\mathrm{df}}$ & Mean Square & $\mathrm{F}$ & Sig. \\
\hline \multirow[t]{3}{*}{ I } & Regression & 101.329 & 4 & 25.332 & 195.768 & $.000^{\mathrm{b}}$ \\
\hline & Residual & 44.384 & 343 & .129 & & \\
\hline & Total & I45.7I3 & 347 & & & \\
\hline
\end{tabular}

a. Dependent Variable: good future

b. Predictors: (Constant), bank shows sincere interest in solving, easy to access, enables satisfaction under one roof, low misspelling of products

This analysis mainly shows that the model can explain $69.2 \%$ of the impact of Integrating Good future by Independent variables such as bank shows sincere interest in solving, easy to access, enables satisfaction under one roof, low misselling of products. This is from the evidence that the Adjusted R Square is 0.692, which also means that remaining 30.8\% on developing Good future for Bancassurance will happen by the factors that are not included in the model.

The analysis findings shows that there is a good strong relationship between developing good future by independent variables such as bank showing sincere interest in solving, easy to access, enables satisfaction under one roof, low mis-selling of products as evidenced by the regression model showing Coefficient of $\mathrm{R}$ as $83.4 \%$.

This result is complimented by the R Square of about $69.2 \%$, which in essence is the proportion of total variance that is explained by the model.

Further the results it also show that there is strong relation between satisfaction under one roof and there is no strong relation between showing interest in solving problems on Bancassurance. This makes us accept the alternate hypothesis $\mathrm{H}_{3}$ and reject $\mathrm{H}_{4}$. That means that the statement "showing interest in solving problems of customers has a significant impact on good future in Bancassurance" is accepted and the statement "providing customer satisfaction under one roof has a significant impact on effectivesness of Bancassurance in building good future" is rejected.

\section{Conclusion}

The life Insurance Industry in India has been progressing at a rapid growth since opening up of the sector. The size of country, adverse set of people combined with problems of connectivity in rural areas, makes insurance selling in India a very difficult task. Life Insurance Companies require good distribution strength and tremendous man power to reach out such a huge customer base. The concept of Bancassurance in India is still in its nascent stage, but the tremendous growth and the potential reflects a very bright future for bancassurance in India.

The success of bancassurance greatly depends upon banks ensuring excellent customers relationship; therefore banks need to strive towards that direction. The fact that the banking operations in India, unlike in other developed countries, are still branch oriented and manually operated vis-à-vis highly mechanized and automated banking channels, viz., internet banking, ATMs, etc. are all the more conducive for flourishing of bancassurance. It's a win-win strategy for the banks as well for the insurance companies, as the banks get their commission for selling the insurance products and in the same way the insurance companies get the wide spread networking of their branches. The prospect of bancassurance is also bright as it is one of the most preferred distribution channels among the customers who wish to buy insurance products. With more incentives and focus in the in specified areas the bank can even have the potential of making more customers to buy insurance products from banks. With bancassurance, company can also take the advantage of more customer base and can become more competitive. Thus, in the coming years Insurance Companies will definitely play a predominant role in the bancassurance industry and thereby can contribute more to the upliftment of the company.

\section{References}

BCG \& Swiss Re Report. (2009). Bancassurance in China - Reaching the Next LevelI8

Bajaj Allianz News Track .(20I I). Bancassurance: Ties that Strengthen26

Chang, P. R., Peng, J. L., \& Fan, C. K. (20II). A comparison of bancassurance and traditional insurer sales channels. The Geneva Papers on Risk and Insurance-Issues and Practice, 36(I), 76-93.

Clipici, E., \& Bolovan, C. (20II). Bancassurance-main insurance distribution and sale channel in Europe. Scientific BulletinEconomic Sciences, II, 54-62.

Fiordelisi, F., \& Ricci,O. (2010). Efficiency in the Life Insurance Industry: What are the Efficiency Gains from Bancassurance; EMFI Working Paper 2, 201020RGA Report (2010); Bridging the Cultural Divide Between Banks \& Life Insurers, 20IOAustralia bancassurance Study2I 
Fan, C. K., Lee, L. T., Tang, Y. C., \& Lee, Y. H. (20I I). Factors of cross-buying intention-bancassurance evidence. African Journal of Business Management, 5(17), 75I I-75I5.

Krstić, B., Vojvodić-Miljković, N., \& Mandić, D. (20II). Bancassurance-new options for the development of serbian financial sector. FACTA UNIVERSITATIS, Series: Economics and Organization, 8(1), I5-29.

Kumaraswamy, D. S. (2012). Bancassurance: Tapping of Insurance into Banking Pursuit. International Journal of Scientific and Research Publications, 2(7), PI-5.

Mukadam, K. (20I I). Bancassurance: A Growing Model; ICSI Paper (A - 487), December,20I I, pp 1727 - I72923

(20I I) Bancassurance: A Growing Model; ICSI Paper (A - 487), December,20I I, pp I727 - I72923

Mishra, N. (2012). BANC ASSURANCE: PROBLEMS AND CHALLENGES IN INDIA. Integral Review: A Journal of Management, 5(I).

Neelamegam, R., \& Veni, K. P. (2008). Bancassurance An Emerging Concept in India. The Joumal, II(3), 49-54.

Sinha, T. (2009); The Indian Insurance Industry: Challenges \& Prospects; Report of Institute of Insurance \& Risk Management, India I7

Sorina, O. C. (2012). Bancassurance development in Europe. International Journal of Advances in Management and Economics, $I(6), 64-69$.

\section{Copyrights}

Copyright for this article is retained by the author(s), with first publication rights granted to the journal. This is an open-access article distributed under the terms and conditions of the Creative Commons Attribution license (http://creativecommons.org/licenses/by/4.0/) 